University of Nebraska - Lincoln

DigitalCommons@University of Nebraska - Lincoln

\title{
Panarchy: opportunities and challenges for ecosystem management
}

\author{
Ahjond Garmestani \\ U.S. Environmental Protection Agency, garmestani.ahjond@epa.gov \\ Dirac Twidwell \\ University of Nebraska, Lincoln, dirac.twidwell@unl.edu \\ David G. Angeler \\ Swedish University of Agricultural Sciences, david.angeler@slu.se \\ Shana Sundstrom \\ University of Nebraska-Lincoln, sundstrom.shana@gmail.com \\ Chris Barichievy \\ Institute for Communities and Wildlife in Africa, University of Cape Town, Cape Town, South Africa
}

See next page for additional authors

Follow this and additional works at: https://digitalcommons.unl.edu/natrespapers

Part of the Natural Resources and Conservation Commons, Natural Resources Management and Policy Commons, and the Other Environmental Sciences Commons

\begin{abstract}
Garmestani, Ahjond; Twidwell, Dirac; Angeler, David G.; Sundstrom, Shana; Barichievy, Chris; Chaffin, Brian C.; Eason, Tarsha; Graham, Nick; Granholm, Dean; Gunderson, Lance; Knutson, Melinda; Nash, Kirsty L.; Nelson, R John; Nystrom, Magnus; Spanbauer, Trisha L.; Stow, Craig A.; and Allen, Craig R., "Panarchy: opportunities and challenges for ecosystem management" (2020). Papers in Natural Resources. 1323. https://digitalcommons.unl.edu/natrespapers/1323
\end{abstract}

This Article is brought to you for free and open access by the Natural Resources, School of at DigitalCommons@University of Nebraska - Lincoln. It has been accepted for inclusion in Papers in Natural Resources by an authorized administrator of DigitalCommons@University of Nebraska - Lincoln. 


\section{Authors}

Ahjond Garmestani, Dirac Twidwell, David G. Angeler, Shana Sundstrom, Chris Barichievy, Brian C. Chaffin, Tarsha Eason, Nick Graham, Dean Granholm, Lance Gunderson, Melinda Knutson, Kirsty L. Nash, R John Nelson, Magnus Nystrom, Trisha L. Spanbauer, Craig A. Stow, and Craig R. Allen 


\title{
Panarchy: opportunities and challenges for ecosystem management
}

\author{
Ahjond Garmestani ${ }^{1,2^{\star}}$, Dirac Twidwell ${ }^{3,4}$, David G Angeler ${ }^{5}$, Shana Sundstrom ${ }^{6}$, Chris Barichievy ${ }^{7}$, Brian C Chaffin $^{8}$, \\ Tarsha Eason $^{1}$, Nick Graham ${ }^{9}$, Dean Granholm ${ }^{10}$, Lance Gunderson ${ }^{11}$, Melinda Knutson ${ }^{12}$, Kirsty L Nash ${ }^{13}$, R John Nelson ${ }^{14}$, \\ Magnus Nystrom ${ }^{15}$, Trisha L Spanbauer ${ }^{16}$, Craig A Stow ${ }^{17}$, and Craig R Allen ${ }^{4,6}$
}

Addressing unexpected events and uncertainty represents one of the grand challenges of the Anthropocene, yet ecosystem management is constrained by existing policy and laws that were not formulated to deal with today's accelerating rates of environmental change. In many cases, managing for simple regulatory standards has resulted in adverse outcomes, necessitating innovative approaches for dealing with complex social-ecological problems. We highlight a project in the US Great Plains where panarchy - a conceptual framework that emerged from resilience - was implemented at project onset to address the continued inability to halt large-scale transition from grass-to-tree dominance in central North America. We review how panarchy was applied, the initial outcomes and evidence for policy reform, and the opportunities and challenges for which it could serve as a useful model to contrast with traditional ecosystem management approaches.

Front Ecol Environ 2020; 18(10):576-583, doi:10.1002/fee.2264

rappling with uncertainty and the unexpected remains at

$\checkmark$ the forefront of contemporary debates in natural resource law and policy (Garmestani et al. 2019). Natural resource law assumes that ecosystems generally operate within a limited envelope of predictability. These laws often do not adequately

\section{In a nutshell:}

- Ecosystem management is constrained by natural resource laws that are ill-suited for dealing with uncertainty

- The project discussed here is one of the first real-world efforts to implement panarchy in a social-ecological system; in this study, panarchy was used to address the inability to sustain grasslands in the Great Plains of North America

- Panarchy was applied to design products (eg outreach documents, maps) to engage law, policy, and management sectors on the adverse outcomes resulting from existing eastern redcedar (Juniperus virginiana) governance

- Initial evidence from policy reform indicates that panarchy can help improve ecosystem management

\footnotetext{
${ }^{1}$ Office of Research and Development, US Environmental Protection Agency, Gulf Breeze, FL ${ }^{\star}$ (garmestani.ahjond@epa.gov); ${ }^{2}$ Utrecht Centre for Water, Oceans and Sustainability Law, Utrecht University School of Law, Utrecht, Netherlands; ${ }^{3}$ Department of Agronomy and Horticulture, University of Nebraska, Lincoln, NE; ${ }^{4}$ Center for Resilience in Agricultural Working Lands, University of Nebraska, Lincoln, NE; ${ }^{5}$ Department of Aquatic Sciences and Assessment, Swedish University of Agricultural Sciences, Uppsala, Sweden; ${ }^{6}$ School of Natural Resources, University of Nebraska, Lincoln, NE; ${ }^{7}$ Institute for Communities and Wildlife in Africa, University of Cape Town,

Cape Town, South Africa; ${ }^{8}$ Department of Society and Conservation, College of Forestry and Conservation, University of Montana,

Missoula, MT; (continued on last page)
}

account for uncertainty and surprises, and even less so the emergent phenomena associated with today's natural disasters, food- and water-security issues, and global rates of species extinctions. Instead, laws often reinforce command-and-control approaches to ecosystem management, and corresponding conservation actions often target simplistic endpoints (Green et al. 2015). Such efforts often attempt to freeze ecosystems in steady states, even though their dynamic behavior is inevitable and ultimately fundamental to the very structure and function of nature (Aubreville 1936; Botkin 1990; Turner 2005). When implemented without consideration of scale, adverse management outcomes may ensue. A classic example is that of coral reefs, where management often fails to account for the impacts that nearby terrestrial ecosystems may have on coral reef systems (Norstrom et al. 2016).

Panarchy, a concept that grew out of resilience and hierarchy theory (Holling 1973; Allen and Starr 1982; Allen et al. 2019), is a useful tool for understanding uncertainty and the unforeseen in an era of rapid environmental change (Gunderson and Holling 2002). A panarchy can be expressed as a conceptual model that emphasizes the inevitable and inherent dynamics of living systems: that is, living systems are complex, adaptive, and undergo stages of growth, conservation, release, and reorganization at many levels of biological organization (Figure 1). Panarchy was developed to avoid tendencies that prevail in ecosystem management, such as interventions that seek to freeze systems at a fixed endpoint, impose rigid constraints over disturbance regimes, and overly constrain extremes in system behavior to a narrow and idealized range of conditions (Gunderson et al. in press).

Here, we present one of the first attempts to implement panarchy at the beginning of a project, as part of efforts to address the failure to halt a biome-scale transition with major conservation implications in North America. Our approach embedded 


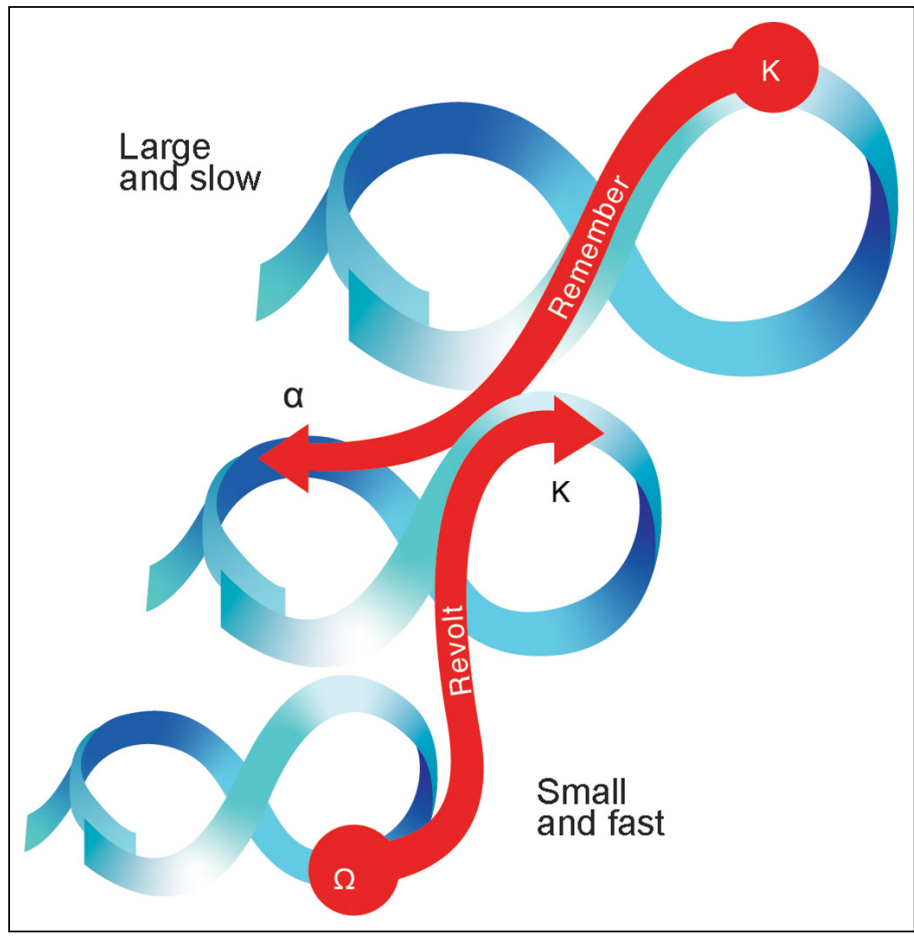

Figure 1. Social-ecological systems are characterized by multiple spatial and temporal scales that can be described as a panarchy (see Gunderson and Holling [2002] for more information): that is, a nested set of adaptive cycles (depicted here by three blue infinity symbols, of increasing size), each representing dynamic change at a functionally relevant scale (adapted from Gunderson and Holling [2002]). Each adaptive cycle portrays phases of growth ( $r$-phase), conservation (K-phase), release ( $\Omega$-phase), and reorganization (a-phase) (Gunderson and Holling 2002). Due to its visualization of multiple scales, dynamism within scales, and interactions across scales (red arrows), panarchy is a promising conceptual framework for addressing problems in the Anthropocene. However, panarchy has not been well integrated into ecosystem management.

panarchy into practices that encouraged scientists to engage non-science partners and audiences - commonly referred to as translational ecology (see Chapin [2017] and other articles in Frontiers in Ecology and the Environment's 2017 Special Issue: https://bit.ly/312RzuB), co-production (Naugle et al. 2019), landscape sustainability science (Wu 2013), or use-inspired science (Keeler et al. 2017). To better explain how panarchy can be put into practice, we describe how our approach aligns with three basic propositions of panarchy (introduced in Allen et al. [2014]): (1) that complex systems are discontinuously structured (ie organized into discrete groups); (2) that complex systems undergo cycles of destruction and renewal; and (3) that cross-scale linkages (eg destruction of many small-scale wetlands resulting in large-scale loss of ecosystem services) are critical to system function. In our example, we describe how panarchy inspired new ways of visualizing and communicating scientific data, the practical approaches used to elucidate the risks of the continued transition of grasslands to woodland dominance for a region that has yet to undergo such a transition, and the initial evidence for policy transformation.

\section{Putting panarchy into ecosystem management}

\section{Case study for an ecosystem in transition}

Panarchy has been used to demonstrate the emerging vulnerability of one of the last remaining intact prairie regions of North America - the 50,000 $\mathrm{km}^{2}$ Nebraska Sandhills - to large-scale vegetation change. The Sandhills represent a grassland region of considerable ecological and human importance. Grassland ecosystems are among the most widely converted and least protected globally (Newbold et al. 2016), and the Sandhills serve as an intact refuge for a diverse array of grassland biodiversity unique to the Great Plains (Johnsgard 2005). They also provide a perennial resource for rural livelihoods (Arterburn et al. 2019), an aquifer used elsewhere in the region for drinking water and agricultural irrigation (Adane et al. 2018), and greater personal security from wildfire disasters (Twidwell et al. 2013b), among other highly valued ecosystem services. The Nebraska Sandhills exhibit near-term vulnerability to invasion by eastern redcedar (Juniperus virginiana), a highly invasive native juniper species that is driving a large-scale transition from grass-to-tree dominance across the Great Plains of North America (Engle et al. 2008). Unlike other parts of the Great Plains, the Sandhills have yet to realize the full suite of social-ecological trade-offs that occur when grasslands transition to juniper woodland dominance, and in no region have these trade-offs been prevented from occurring. We used panarchy as a tool to highlight the importance of the relatively intact Sandhills region in educational seminars and workshops involving a diverse network of government agency professionals, private landowners, and legislators.

\section{Proposition 1: complex systems are discontinuously structured}

A general challenge in Great Plains grassland conservation has been to confront different conceptual models of vegetation change over time, especially when these different models recommend different management actions. One such overly simplistic model is that of a monotonic trajectory of succession and retrogression (Twidwell et al. 2013a). Successional retrogression, in terms of traditional ecosystem management, contends that changes in successional trajectories (such as the invasion of woody species into grasslands) represent an undesired trajectory that can be reversed by management actions focused on the removal of woody species. Management interventions of this kind assume that such removals would allow the system to return to an idealized grass-dominated state. Indeed, mechanical and chemical interventions have been largely relied upon for decades as the best practices for mitigating woody plant encroachment into grasslands in an effort to retrogressively manage succession. To deconstruct this long-held perspective, we leveraged new data and maps to communicate the general problem of assuming vegetation can be managed retrogressively along a continuous distribution 


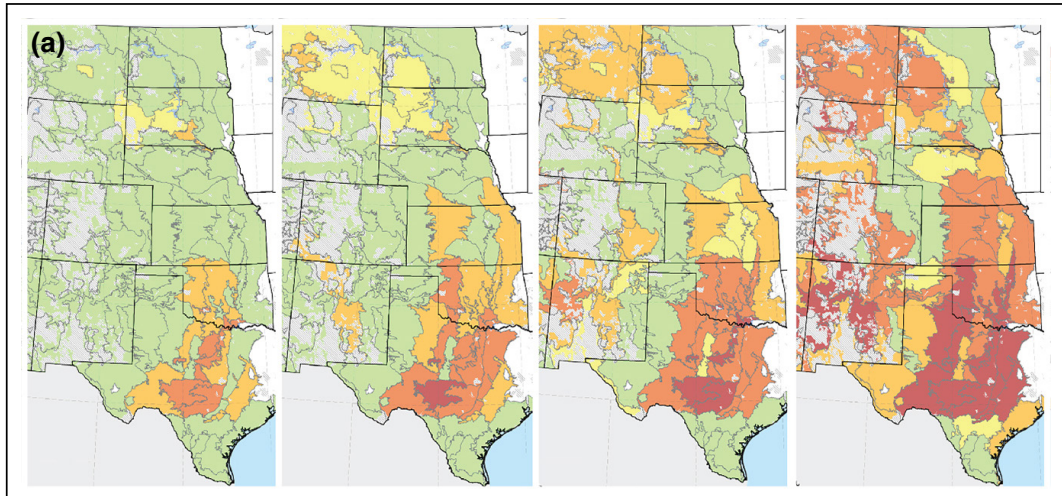

Projected expansion of Juniperus woodlands without intervention

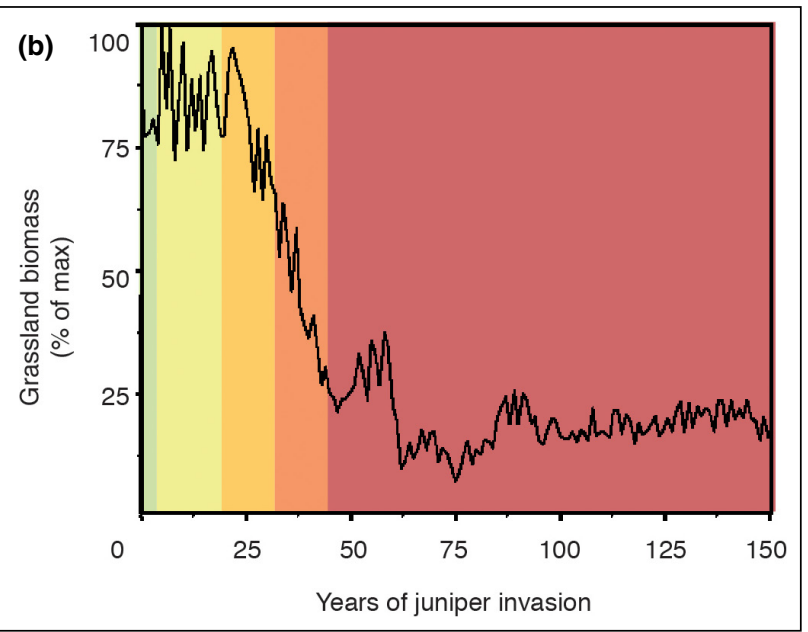

Figure 2. The imminent Great Plains regime shift from grasslands to juniper woodlands. Long-term data trends were adapted from Fuhlendorf et al. (2008), and maps were adapted from national-level vegetation monitoring (USDA Natural Resources Conservation Service [2010]; https://bit.ly/3boWEA0) to show future vulnerability based on the current stage of the invasion process (using juniper abundance as a proxy). In the four maps depicted in (a), the left-most map shows survey sites where juniper woodlands comprise greater than $50 \%$ cover. The remaining three maps signify areas experiencing incipient juniper invasions, which will progress (from left to right) toward juniper woodlands in the future without adaptive management interventions. The colors in (a) correspond to the colors and associated values in (b). New data products are now available that better capture changes in woody plant abundance over time, and further confirm the vulnerability of the region to further grassland displacement and tree expansion (Jones et al. 2018; Uden et al. 2019).

(ie grasslands can easily be restored with mechanical and chemical removal of trees). We first introduced evidence of extensive juniper invasion at regional conferences and workshops, demonstrating a pattern of invasion of grasslands spanning multiple US states (Figure 2, adapted from USDA NRI [2010]). The key message was to reveal heightened vulnerability to an intact grassland region in Nebraska, and to engage the general denial among citizens and resource professionals that this environmental problem "was not possible here". Tens of millions of taxpayer dollars are spent each year in the US on brush management (Twidwell et al. 2013a). Yet, even with federal subsidies, the cost of implementing brush management interventions in the southern Great Plains resulted in localized management actions (average project size 15-20 ha) that were not keeping pace with the relatively rapid and widespread grassland-to-juniper woodland conversions (Twidwell et al. 2013b).

To understand the limitations of assuming a continuous distribution of vegetation change, and the implications of managing based on this assumption, we then provided stakeholders with decades of scientific research on the risks of continuing with current policy and the limitations of the brush management paradigm. The causes and consequences of the expansion of the eastern redcedar woodland regime have been rigorously studied in the southern half of the Great Plains (eg Briggs et al. 2002; Engle et al. 2008), but only one-third of sampled Nebraskans recognized eastern redcedar as a resource concern (Nebraska Annual Social Indicators Survey 2016; https://bit.ly/3h5xbhT). Given that Nebraska is home to the $50,000 \mathrm{~km}^{2}$ Sandhills prairie ecosystem (one of the last remaining intact grasslands in North America), the distribution and dissemination of scientific knowledge became a top priority. This led to the creation of the Eastern
Redcedar Science Literacy Project (http://cedarliteracy.unl.edu), a comprehensive online clearinghouse for people to access scientific research on the spread and impacts of eastern redcedar encroachment into grasslands. The Eastern Redcedar Science Literacy Project adapted the guiding principles used for international social-ecological assessments and climate-change research (eg Millennium Ecosystem Assessment, Intergovernmental Panel on Climate Change, Intergovernmental Science-Policy Platform on Biodiversity and Ecosystem Services) for the purposes of regional outreach (eg local or state levels).

An interesting outcome emerged while discussing the relevant historical scientific literature with non-academic partners: it became obvious that traditional management practices targeted a narrow range of the vegetation hierarchy. Removing individual trees and dense woody patches on a fraction of an individual's property was the default target, an approach that disregarded policies and programs necessary for addressing the broader issue of vegetation change (WebFigure 1; Figure 3). No formal policies or planning horizons had been implemented at scales beyond the patch level or at the level of seeds or seed dispersal, despite the latter being the basis for eastern redcedar reproduction and spread. This oversight has now become a new focal point of research and proactive management.

\section{Proposition 2: complex systems undergo cycles of destruction and renewal}

A second challenge of grassland conservation is the tradition of preventing disturbances (eg fire) perceived to compete with grazing animals (see also Botkin [1990]; a traditional approach focusing on preventing wildfire was revised in order to alter management for Kirtland's warbler [Setophaga 


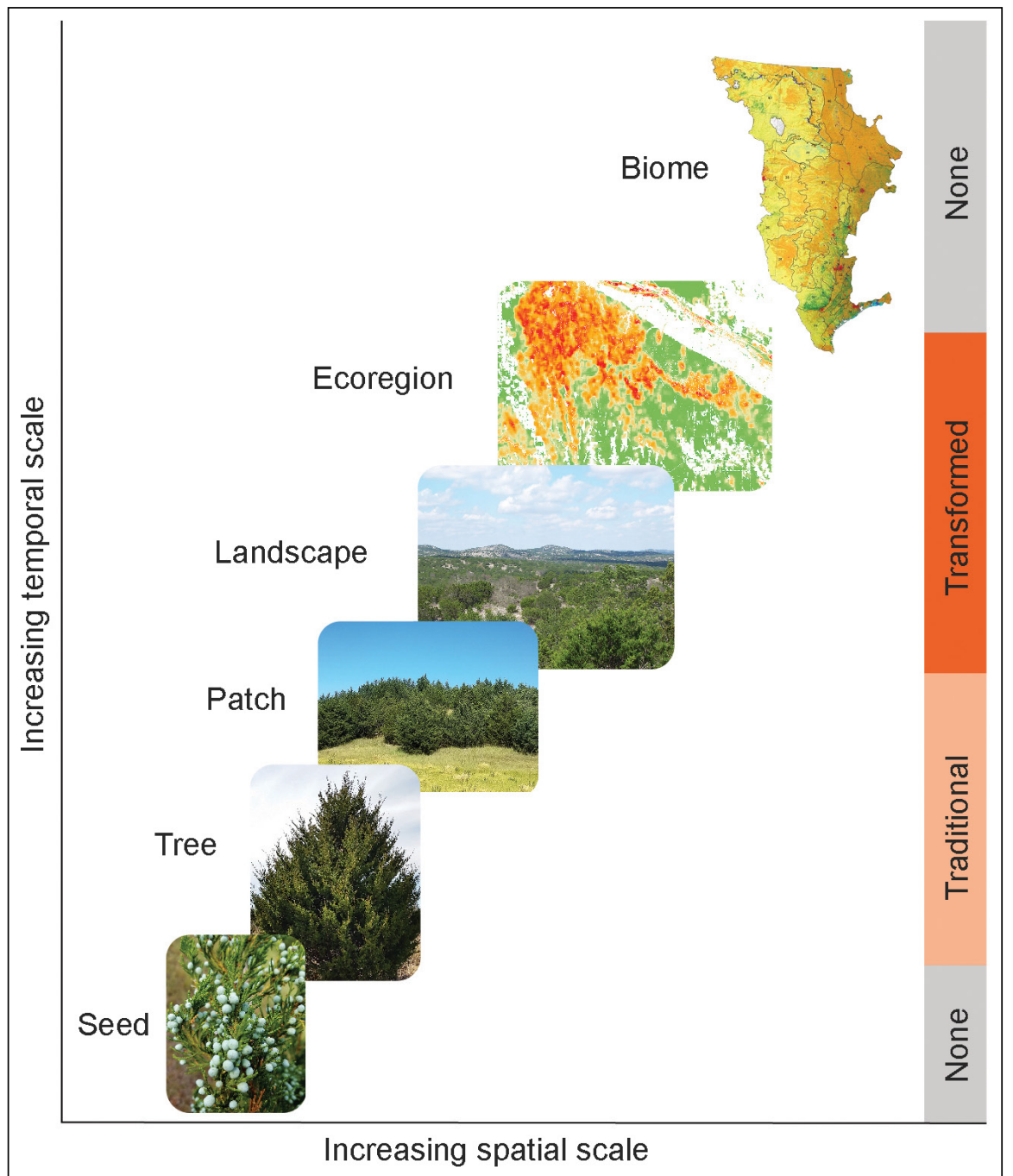

Figure 3. Traditional policies incentivize a narrow range of scales in the woody encroachment process and promote the targeting of individual trees and tree patches (USDA Natural Resources Conservation Service EQIP Code 314). In contrast, panarchy emphasizes the crossscale interdependencies of pattern and process in nature, and the need to incorporate crossscale considerations into law and policy. Examples of transformed policy, representing new scales of emphasis in the system, have emerged in Nebraska and include transformations spanning landscape to ecoregional scales, such as: federal agency funding for landowneroperated prescribed burning cooperatives, changes to state policy to discontinue planting eastern redcedar (Juniperus virginiana), and heterogeneity-based fire management introduced via the USDA Conservation Stewardship Program. Mapping the scales at which policies operate as a panarchy (shown here as nested scales of organization from seed to biome, each representing an interconnected series of adaptive cycles in a panarchy) identifies (1) policy gaps in the system, (2) policy mismatches that may occur across scales and how to reconcile adverse policy, and (3) missing policy structures in the system. There are still no policies focused on seed dispersal, the biological basis for woody plant encroachment by eastern redcedar, or the biome scale, which are needed if the same grassland resources from this system are to be secured for future generations.

kirtlandii] after it was discovered that the bird species depends on periodic fires in its breeding areas), the reliance on chemical or mechanical techniques to target emergent "weed" species and to serve as a replacement for historical disturbances (irrespective of native or non-native status), and the use of reseeding techniques to accelerate ecological succession and restore idealized critical functionality back to a high-biomass condition. All of these approaches focus on a single reference point (consistent with the K-phase of the adaptive cycle; Figure 1) and a single scale of system behavior, both of which fundamentally contradict the inherent realities of ecological dynamics. The irony is that such an approach facilitates widespread, regional encroachment of eastern redcedar, as it is a fire-sensitive and historically rare woody plant.

Restoring fire and re-establishing cycles of "destruction" and renewal in grasslands became a statewide, landowner-led priority. One of the co-authors of this paper (DT) participated in the founding of the Nebraska Prescribed Fire Council (circa 2015), which organized landowners across the state and emphasized core principles of the adaptive cycle when describing the role of fire in maintaining grassland dominance. Key messages from fire ecology research were adopted by private and public partners within the group, countering long-held perceptions of fire as simply a destructive force of nature that would lead to large-scale erosion in the Sandhills (Arterburn et al. 2018). In fact, fire was less expensive than other management options, required fewer external inputs, and created heterogeneity that reinforced grassland biodiversity and productivity (Fuhlendorf et al. 2012). Panarchy was used in outreach materials, educational seminars, and workshops to foster a shift from the prevailing view, which emphasized the forward stage in the adaptive cycle (succession) and avoided the backward stage (release and reorganization) (depicted in Figure 1), to an alternative perspective where all stages of the adaptive cycle were seen as important in grassland conservation (Figure 4).

\section{Proposition 3: cross-scale linkages are critical to system function}

A third major challenge for grassland conservation in the Sandhills is that afforestation programs in Nebraska have for more than a century exported local knowledge to promote government policies and initiatives that introduced trees into temperate grasslands around the world. The afforestation footprint within North America's temperate grassland biome is exceptional (Figure 5) and has long promised to bring prosperity and economic stability to a region known for its human-made disasters (eg the Dust 
Bowl). Afforestation efforts often ignore crossscale linkages inherent in panarchy, particularly the recognition that local interventions can lead to changes at higher levels of organization and in the surrounding grassland matrix (Donovan et al. 2019).

In Nebraska and elsewhere in the Great Plains, small-scale plantings of eastern redcedar trees set the stage for woody plant encroachment and changed the scale of impact from a landowner problem to a biome-level crisis (Figures 2 and 3). Ecologists have studied the spread and impact of trees used in afforestation programs for decades (Farley et al. 2005; Engle et al. 2008). This global pattern of afforestation has been termed the "tyranny of trees" (Veldmen et al. 2015), with documented collapses of a suite of unique ecosystem services in grasslands, which among biomes have the least amount of conservation protection globally (Hoekstra et al.2005; Van Auken 2009; Twidwell et al. 2013b). The biome-level crisis has been driven by humans increasing dispersal distance by an order of magnitude, increasing the number of propagules present in grasslands, and intervening to prevent spatially contiguous processes (eg fire) that formerly controlled the spread of eastern redcedar.

We helped foster information sharing at public meetings to counter the widespread denial that existed in Nebraska concerning the potential for tree-planting programs to contribute to woody plant encroachment. A central challenge for collaboration became obvious: contrasting utilitarian-driven land-use ethics (Leopold 1949) existed among different natural resource agencies. For instance, state forest service agencies are legislatively obligated to manage State Forest lands, but also to support private forestry efforts. On the other hand, the US Fish and Wildlife Service, various state wildlife agencies, conservation-oriented non-governmental organizations (NGOs; eg The Nature Conservancy), and the US Forest Service, which also manages National Grasslands, are charged with conserving grasslands by controlling trees that may invade from the surrounding landscape. No explicit decision authority exists to address these contradictory goals, leading to a classic equilibrium-based approach to conservation where investments are made simultaneously to plant trees (for a perceived utilitarian benefit) and to control the spread of those same trees (in an effort to avoid known negative trade-offs to society associated with afforestation) (Roberts et al. 2018).

\section{Initial evidence for policy reform}

Explicitly incorporating panarchy into our research agenda has led to policy reform, and those changes are occurring at multiple scales (Figure 3). Legislative advisory councils have since formed, and the most commonly planted tree in the Great Plains - eastern redcedar - is now listed as one of the species most capable of regional and statewide consequences to ecosystem services (Nebraska Invasive Species Council, https://neinvasives.com/species/plants/easternredcedar). Roundtables have been created to bring scientists, private citizens, and representatives of government agencies, NGOs, and industry together with the goal of informing legislators on the scientific consensus, which was made publicly available through our literacy campaigns (Eastern Redcedar Science Literacy Project; http://cedarliteracy.unl. edu). Federal technical guidance for private landowners has recently been changed at the state level in response to our research and continues to be evaluated within the US Department of Agriculture Natural Resources Conservation Service (USDA NRCS). Technical programs within the USDA that promote conflicting guidance, in which tree planting is recommended in one program and methods for control are outlined in another, are also under agency revision (USDA NRCS, State Conservationist Memo, August 2019; https:// bit.ly/32VCLha). In Nebraska, policies were changed for one Natural Resource District, which was formerly a primary seller and distributor of eastern redcedar. Most recently, a legislative resolution (LR 387) was passed in the Nebraska state legislature in 2019 to increase awareness of eastern redcedar and the causes, consequences, and impacts of its continued spread throughout grasslands.

These examples represent the early stages of policy reform, but such changes are new and their alignment with the state-ofthe-science is inconsistent. Traditional perspectives of rangeland management are difficult to overcome (Fuhlendorf et al. 2012). 


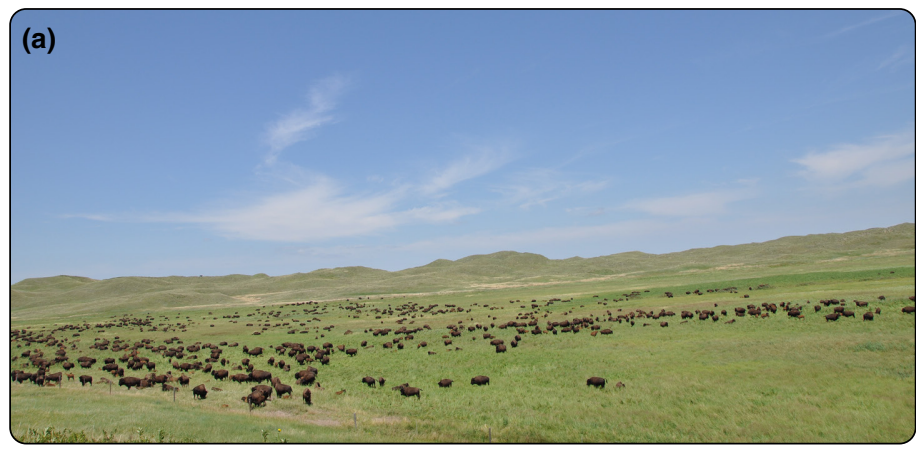

(b)

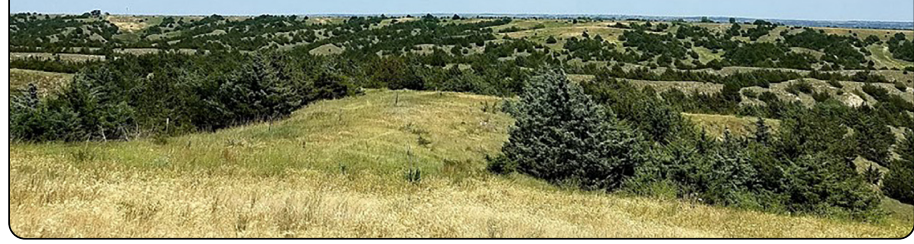

Figure 5. Federal policies and programs have long promoted afforestation in the Great Plains biome of North America. Shown here are examples of (a) a relatively undisturbed grassland and (b) a former grassland transformed into a juniper woodland after invasion by eastern redcedar from tree plantings. Contributions to woody invasions and broad-scale consequences were unanticipated at the onset of conservation policies, such as the Prairie States Forestry Project, that promoted afforestation at a biome scale.

Afforestation and brush control, which are affiliated not only with substantial economic investments but also with established cultural beliefs and political ideologies, have been promoted as best practices for more than a century. Nonetheless, laws and policies (related to eastern redcedar) are in a stage of reassessment and reorganization and at a broader range of scales than had been achieved with previous scientific engagement.

\section{Moving forward with panarchy}

The interaction between top-down (eg federal-state policies encouraging tree planting) and bottom-up (eg individual, local control of eastern redcedar) aspects of this social-ecological system allowed for the identification of rapidly changing baselines within a largely intact prairie region. Due to the clear effects of eastern redcedar invasion manifesting at multiple scales, it became easier to engage stakeholders about this complex problem. In turn, an understanding of panarchy provided participants in the above-mentioned public meetings with a better recognition of the scales at which management actions should occur to account for the scale of socialecological change in the woody plant encroachment process, a crucial point given that policy and management often focus instead on the scales that expedite program delivery (Green et al. 2014; Mayer et al. 2016). Rigid perspectives focusing on a single scale or narrow range of scales, a single species, or a single commodity often lead to undesirable management outcomes (Green et al. 2015). Consistent with theoretical expectations (Vasseur et al. 2017), this example from the Great Plains illustrates that generating complementary policy structures across scales increases the chances of generating desirable environmental outcomes.

Although considerable progress has been made in addressing cross-scale challenges for governance in the Nebraska Sandhills project, there remain challenges that will require further engagement of research with law, policy, and management moving forward. For example, there is a need to link laws and policies to quantitative measures of system condition (Garmestani and Allen 2014). Several approaches appear promising in this respect for improving ecosystem management, as they are based on a systems perspective; these include discontinuity analysis (Nash et al. 2014), multivariate timeseries modeling (Angeler et al. 2011), spatial analysis for early warning indicators (Roberts et al. 2019), and advanced screening techniques for regime shift detection (Uden et al. 2019). Further application of such methods may provide additional insight into how coupled systems of humans and nature function, and how to better manage them (Soranno et al. 2014).

\section{Conclusion}

Here, we highlight one of the first real-world efforts to implement panarchy to address accelerating environmental change. In a region yet to experience the full set of consequences that correspond to large-scale transition from grasslands to juniper woodlands, there has been growing awareness of the conflicting priorities and consequences of traditional policy and management of eastern redcedar, the importance of accounting for cross-scale interactions in management decisions, and consideration among legislative bodies on how to reform laws and policies based on the application of new knowledge developed from this research.

We foresee numerous opportunities in which panarchy can be used to improve environmental governance (Gunderson $e t$ al. in press). For instance, little has been done to quantify aspects of panarchy and more directly link those approaches to ecosystem management. Incorporating panarchy at project inception, when appropriate, can provide a more holistic framework for advancing governance of social-ecological systems (Gillard et al. 2017). In turn, applying panarchy requires collaboration to circumvent future undesired social-ecological regimes, consistent with these early examples of transformation pertaining to eastern redcedar in grassland regions of the Great Plains.

\section{Acknowledgements}

The findings and conclusions in this manuscript have not been formally disseminated by the US Environmental Protection Agency and should not be construed to represent any agency determination or policy. Any use of trade names 
is for descriptive purposes only and does not imply endorsement by the US Government. Funding was provided by the US Geological Survey Powell Center for Analysis and Synthesis; Nebraska Game \& Parks Commission (W-125-R-1); US Strategic Environmental Research and Development Program (SERDP; W912HQ-15-C-0018); the US National Science Foundation (OIA-1920938); the August T Larsson Foundation of the Swedish University of Agricultural Sciences; and the Swedish Research Council Formas (2014-1193) and VR (20145828). This is Great Lakes Environmental Research Laboratory (GLERL) contribution number 1942.

\section{References}

Adane ZA, Nasta P, Zlotnik V, and Wedin D. 2018. Impact of grassland conversion to forest on groundwater recharge in the Nebraska Sand Hills. J Hydrol 15: 171-83.

Allen CR, Angeler DG, Chaffin BC, et al. 2019. Resilience reconciled. Nat Sustain 2: 898-900.

Allen CR, Angeler DG, Garmestani AS, et al. 2014. Panarchy: theory and application. Ecosystems 17: 578-89.

Allen TFH and Starr TB. 1982. Hierarchy: perspectives for ecological complexity. Chicago, IL: University of Chicago Press.

Angeler DG, Drakare S, and Johnson RK. 2011. Revealing the organization of complex adaptive systems through multivariate time series modeling. Ecol Soc 16: art5.

Arterburn JR, Twidwell D, Schacht WH, et al. 2018. Resilience of Sandhills grassland to wildfire during drought. Rangeland Ecol Manag 71: 53-57.

Arterburn JR, Twidwell D, Wonkka CL, et al. 2019. Restoring firegrazer interactions to pursue heterogeneity in Sandhills prairie. Front Ecol Evol 7: 365.

Aubreville A. 1936. La foret coloniale: les forets de l'Afrique Occidentale Francaise. Paris, France: Académie des sciences colonials.

Botkin DB. 1990. Discordant harmonies: a new ecology for the twenty-first century. New York, NY: Oxford University Press.

Briggs JM, Hoch GA, and Johnson LC. 2002. Assessing the rate, mechanisms, and consequences of the conversion of tallgrass prairie to Juniperus virginiana forest. Ecosystems 5: 578-86.

Chapin III FS. 2017. Now is the time for translational ecology. Front Ecol Environ 15: 539.

Donovan VM, Burnett JL, Bielski CH, et al. 2019. Social-ecological landscape patterns predict woody encroachment from native tree plantings in a temperate grassland. Ecol Evol 8: 9624-32.

Engle DM, Coppedge BR, and Fuhlendorf SD. 2008. From the Dust Bowl to the green glacier: human activity and environmental change in Great Plains grasslands. In: Van Auken OW (Ed). Western North American Juniperus communities: a dynamic vegetation type. New York, NY: Springer.

Farley KA, Jobbágy EG, and Jackson RB. 2005. Effects of afforestation on water yield: a global synthesis with implications for policy. Glob Change Biol 11: 1565-76.

Fuhlendorf SD, Archer SA, Smeins F, et al. 2008. The combined influence of grazing, fire, and herbaceous productivity on tree-grass interactions. In: Van Auken OW (Ed). Western North American
Juniperus communities: a dynamic vegetation type. New York, NY: Springer.

Fuhlendorf SD, Engle DM, Elmore RD, et al. 2012. Conservation of pattern and process: developing an alternative paradigm of rangeland management. Rangeland Ecol Manag 65: 579-89.

Garmestani A, Ruhl JB, Chaffin BC, et al. 2019. Untapped capacity for resilience in environmental law. P Natl Acad Sci USA 116: 19899-904.

Garmestani AS and Allen CR. 2014. Social-ecological resilience and law. New York, NY: Columbia University Press.

Gillard R, Gouldson A, Paavola J, and Van Alstine J. 2017. Can national policy blockages accelerate the development of polycentric governance? Evidence from climate change policy in the United Kingdom. Global Environ Chang 45: 174-82.

Green OO, Garmestani AS, Hopton ME, and Heberling MT. 2014. A multi-scalar examination of law for sustainable ecosystems. Sustainability 6: 3534-51.

Green OO, Garmestani AS, Allen CR, et al. 2015. Barriers and bridges to the integration of social-ecological resilience and law. Front Ecol Environ 13: 332-37.

Gunderson L, Allen CR, and Garmestani A. Applied panarchy: applications and diffusion across disciplines. Washington, DC: Island Press. In press.

Gunderson LH and Holling CS. 2002. Panarchy: understanding transformations in human and natural systems. Washington, DC: Island Press.

Hoekstra JM, Boucher TM, Ricketts TH, and Roberts C. 2005. Confronting a biome crisis: global disparities of habitat loss and protection. Ecol Lett 8: 23-29.

Holling CS. 1973. Resilience and stability of ecological systems. Annu Rev Ecol Evol S 4: 1-23.

Johnsgard PA. 2005. The nature of Nebraska: ecology and biodiversity. Lincoln, NE: University of Nebraska Press.

Jones MO, Allred BW, Naugle DE, et al. 2018. Innovation in rangeland monitoring: annual, $30 \mathrm{~m}$, plant functional type percent cover maps for US rangelands, 1984-2017. Ecosphere 9: e02430.

Keeler BL, Chaplin-Kramer R, Guerry AD, et al. 2017. Society is ready for a new kind of science - is academia? BioScience 67: 591-92.

Leopold A. 1949. A Sand County almanac, and sketches here and there. Oxford, UK: Oxford University Press.

Mayer AL, Buma B, Davis A, et al. 2016. How landscape ecology informs global land-change science and policy. BioScience 66: 458-69.

Nash KL, Allen CR, Angeler DG, et al. 2014. Discontinuities, crossscale patterns, and the organization of ecosystems. Ecology 95: 654-67.

Naugle DE, Allred BW, Jones MO, and Twidwell D. 2019. Coproducing science to inform working lands: the next frontier in nature conservation. BioScience 70: 90-96.

Newbold T, Hudson LN, Arnell AP, et al. 2016. Has land use pushed terrestrial biodiversity beyond the planetary boundary? A global assessment. Science 353: 288-91.

Norstrom AV, Nystrom M, Jouffray JP, et al. 2016. Guiding coral reef futures in the Anthropocene. Front Ecol Environ 14: 490-98.

Roberts CP, Allen CR, Angeler DG, and Twidwell D. 2019. Shifting avian spatial regimes in a changing climate. Nat Clim Change 9: 562. 
Roberts CP, Uden DR, Allen CR, and Twidwell D. 2018. Doublethink and scale mismatch polarize policies for an invasive tree. PLoS ONE 13: $\mathrm{e} 0189733$.

Soranno PA, Cheruvelil KS, Bissell EG, et al. 2014. Cross-scale interactions: quantifying multi-scaled cause-effect relationships in macrosystems. Front Ecol Environ 12: 65-73.

Turner MG. 2005. Landscape ecology: what is the state of the science? Annu Rev Ecol Evol S 36: 319-44.

Twidwell D, Allred BW, and Fuhlendorf SD. 2013a. National-scale assessment of ecological content in the world's largest land management framework. Ecosphere 4: 1-27.

Twidwell D, Rogers WE, Fuhlendorf SD, et al. 2013b. The rising Great Plains fire campaign: citizens' response to woody plant encroachment. Front Ecol Environ 11: e64-71.

Uden DR, Twidwell D, Allen CR, et al. 2019. Spatial imaging and screening for regime shifts. Front Ecol Evol 7: 407.

USDA Natural Resources Conservation Service. 2010. 2010 National Resources Inventory Rangeland Resource Assessment. https://bit. ly/3boWEAO. Viewed 20 Aug 2020.

Van Auken OW. 2009. Causes and consequences of woody plant encroachment into western North American grasslands. J Environ Manage 90: 2931-42.

Vasseur L, Horning D, Thornbush M, et al. 2017. Complex problems and unchallenged solutions: bringing ecosystem governance to the forefront of the UN sustainable development goals. Ambio 46: 731-42.

Veldmen JW, Overbeck GE, Negreiros D, et al. 2015. Tyranny of trees in grassy biomes. Science 347: 484-85.

Wu J. 2013. Landscape sustainability science: ecosystem services and human well-being in changing landscapes. Landscape Ecol 28: 999-1023.

\section{Supporting Information}

Additional, web-only material may be found in the online version of this article at http://onlinelibrary.wiley.com/doi/ 10.1002/fee.2264/suppinfo

${ }^{9}$ Lancaster Environment Centre, Lancaster University, Lancaster, UK;

${ }^{10}$ US Fish and Wildife Service (USFWS), Bloomington, MN;

${ }^{11}$ Department of Environmental Sciences, Emory University, Atlanta, GA;

${ }^{12}$ Region 3 Refuges, USFWS, La Crosse, WI; ${ }^{13}$ Centre for Marine

Socioecology and Institute for Marine and Antarctic Studies, University of Tasmania, Hobart, Australia; ${ }^{14}$ Department of Biology, Centre for Biomedical Research, University of Victoria, Victoria, Canada;

${ }^{15}$ Stockholm Resilience Centre, Stockholm University, Stockholm, Sweden; ${ }^{16}$ Department of Environmental Sciences, University of Toledo, Toledo, $\mathrm{OH} ;{ }^{17}$ NOAA Great Lakes Environmental Research Laboratory, Ann Arbor, $M I$

\section{IIIF Fontersescopics}

\section{Being in love and not being eaten}

(2) exual cannibalism is a well-known example of sexual conflict in spiders. In many species of spiders, the males - while searching for, courting, and mating with conspecific females - are often killed and consumed by their real or potential mates. However, does sexual conflict induce counter-adaptations in the victims, which in this case could help the males avoid being eaten during or after courtship?

The funnel-web spider (Thomisus guangxicus) provides a possible clue. This spider, which belongs to the crab spider family Thomisidae, occupies an ecological niche within the woods of South China.

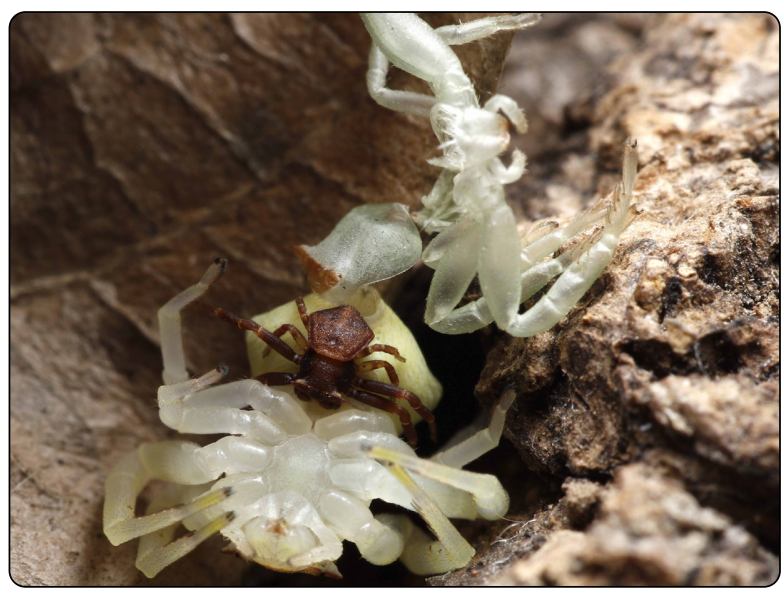

We observed that male funnel-web spiders may escape sexual cannibalism by copulating with molting or recently molted females, which are soft and unable to attack. Such "opportunistic mating" represents an example of behavioral plasticity, which allows individuals to respond to variations in their ecological and social environment in order to cope with a novel scenario. The example described here provides an exciting future possibility: to investigate sexually antagonistic coevolution in a largely unstudied mating system.

Jin Zhou ${ }^{1}$ and Feng Lu ${ }^{2}$ 'Shenzhen International Graduate School, Tsinghua University, Shenzhen, China; ${ }^{2}$ College of Life Sciences and Oceanography, Shenzhen University, Shenzhen, China doi: $10.1002 /$ fee.2283

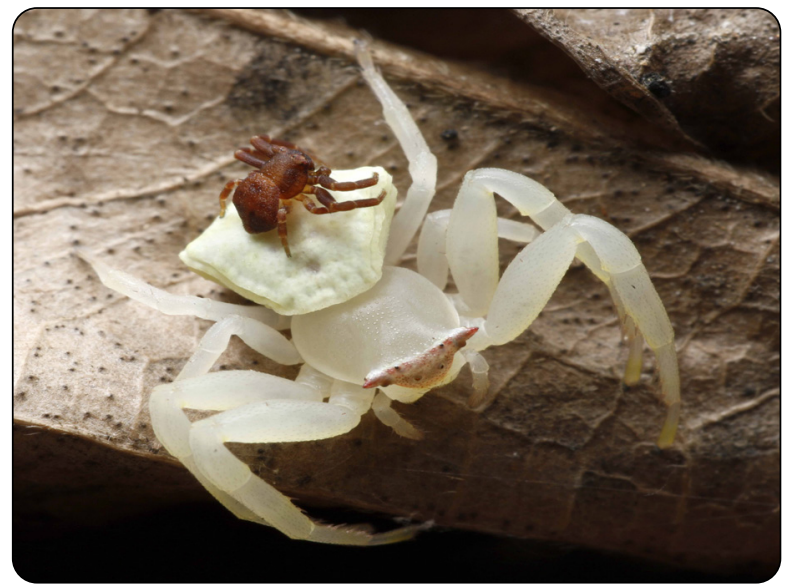




\section{A Garmestani et al. - Supporting Information}

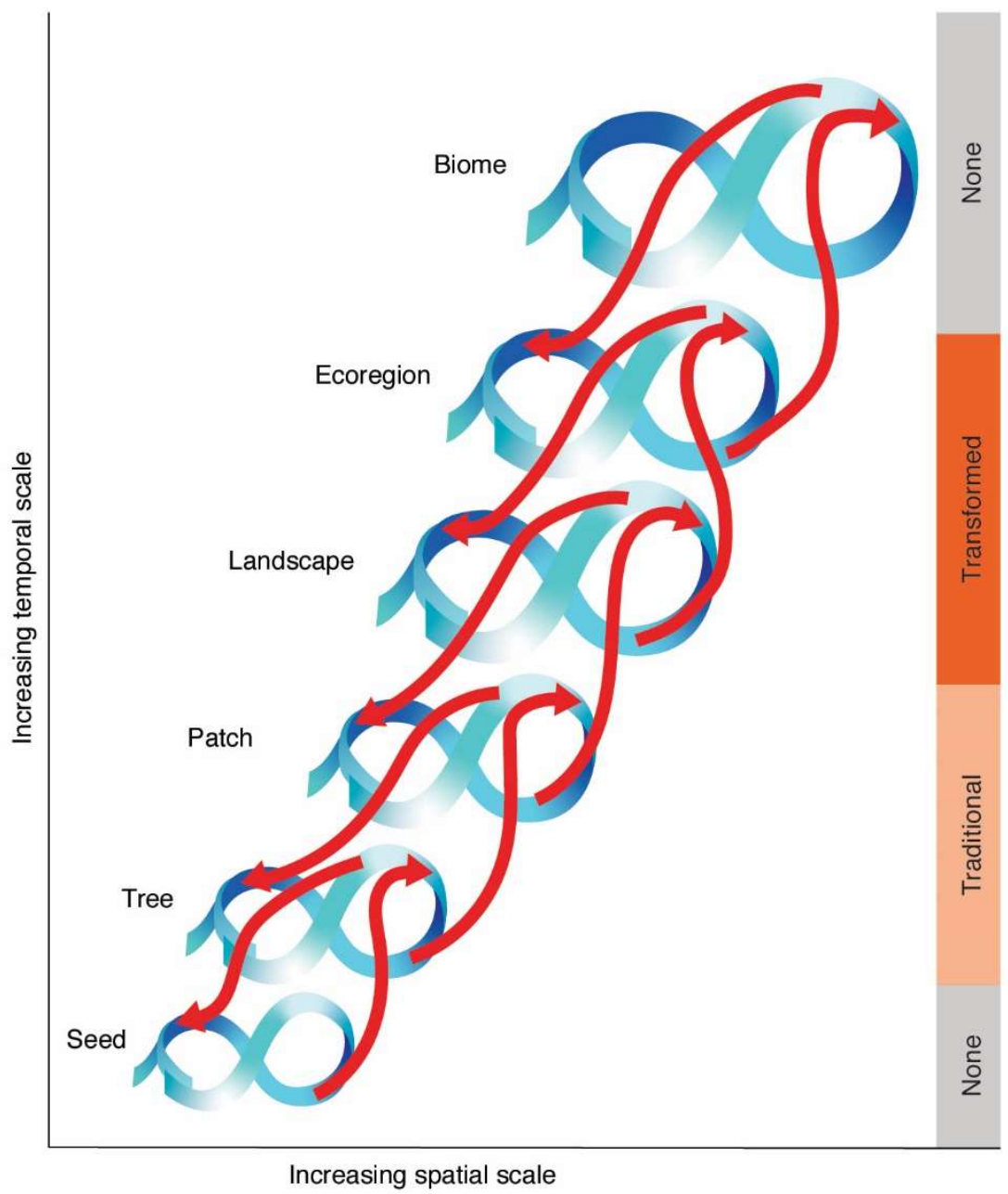

WebFigure 1. New brush management policies have emerged, inspired by panarchy approaches. Shown here are ecosystem scales, with corresponding levels of policy implementation. 